\title{
The Atlas of Izmir/Smyrna
}

Güven İncirlioğlu*

The Atlas of Izmir/Smyrna is an artist's book in preparation, consisting of photographic images and an essay. The following examples illustrate how the photographs will appear in the book, organized according to "types." The photographs are taken through roughly the last four years and are still being edited. The essay is a compilation of research and a set of up to date impressions that I wrote over time and is almost complete. The text and images are not proposed to be complementary: they will have an indirect mutual effect and they are not intended to be descriptive of each other. In short, the book aims at a comprehensive and contemporary panorama of the city of Izmir.

To understand the transformation that the cities in Turkey went through in the last one hundred years, one has to look into historical, sociological, demographic and other related phenomena. Besides these, the more recent makeover of the cities is indexed to a variety of actors that claim stakes on urban space and indeed, to neo-liberal policies. Even though better planned changes are implemented in Izmir today, the urban decay and the damage to the historic city in the past are akin to other cities. Planned to include different "species" of urban forms, spaces, physical environment and the residents, this work of typologies, through a comparative knowledge on the members of a type, aspires to bring out the experiential and artistic, rather than the objective and encyclopedic. In this case, the approach to typologies oscillate in between the photographic convention and the urban subjects.

The photographs mostly look into the urban space and its periphery and they try to reconstruct a retrospective "image of the city," as much as this ambitious task can be realized. These images and writings represent a personal challenge to understand the changes that the city underwent through time after a 30-year absence, from adolescence to middle age. They also represent a desire to understand the past, a kind of archaeology of urban and natural space as it refers to human psyche.

For me, what makes Izmir interesting to look into has a personal basis. But any city of this size should be of some interest even when it is not frequently included in today's travel itineraries, and not closely connected to cultural, industrial, and financial hubs of the world. Even when the city looks homogenous in demographic terms, with a population close to four million one expects microcosms of sociological interest, and a number of new academic literature attests to this. The dramatic history of the city from a provincial setting with 10.000 residents in late 17th century, to that of the most cosmopolitan and "European" Ottoman port in late 19th century and finally to its downfall and a new face after 1922 is also of interest to many historians. Smyrna also has a very special place in Armenian, Jewish, Levantine and especially Greek imagination, a mixture of sadness and pride, of feelings projected to a distant past by the descendants of Smyrniots all over the world.

\footnotetext{
* İzmir University of Economics, Visual Communication Design; xurban.net
} 


\section{İzmir/Smyrna Atlası}

İzmir/Smyrna Atlası fotoğrafik imgeler ve bir denemeden oluşan hazırlık safhasındaki bir sanatçı kitabı. Aşağıdaki örnekler fotoğrafların "tipler"e göre düzenlenmiş olarak kitapta nasıl yer alacağını gösteriyor. Fotoğraflar yaklaşık olarak son dört yılda çekildi ve hâlâ işleniyor. Deneme, bir araştırmanın ve zaman içinde kaleme aldığım güncel bir izlenimler kümesinin derlemesi ve yaklaşık olarak tamamlanmış durumda. Metin ve imgelerin birbirini tamamlamaları öngörülmüyor: Dolaylı bir karşılıklı etkiye sahip olacaklar; birbirlerini betimlemeleri tasarlanmıyor. Sözün kısası kitap İzmir şehrinin kapsamlı ve çağdaş bir panoramasını sunmayı amaçlıyor.

Son bir yüzyılda Türkiye'deki şehirlerin dönüşümünü anlamak için tarihsel, sosyolojik, demografik ve diğer ilintili fenomenlere bakılmalı. Bunların yanı sıra, şehirlerin daha yakın zamanlı görünüm değiştirmesi, kentsel mekândan hak talebinde bulunan bir dizi farklı aktöre ve aslında neo-liberal politikalara endekslenmiştir. Bugün İzmir'de daha iyi planlanmış değişiklikler uygulanıyor olsa dahi, geçmişteki kentsel çürüme ve tarihi şehre verilen zarar, diğer şehirlere benzer. Farklı "tür"lerde kentsel biçimler, mekânlar, fiziksel çevre ve şehir sakinleri içermesi planlanan bu tipolojiler çalışması, bir tipe mensup üyeler hakkında karşılaştırmalı bilgi aracılığıyla, nesnel ve ansiklopedik olandan çok deneysel ve sanatsal olanı ortaya çıkarmayı amaçlıyor. Bu durumda tipolojilere yaklaşım, fotoğrafik konvansiyon ile kentsel özneler arasında salınıyor.

Fotoğraflar çoğunlukla kentsel mekâna ve çeperine bakıyor ve bu iddialı çalışmanın gerçekleştirilebileceği ölçüde "şehrin imgesi”ni retrospektif olarak kurmaya çalışıyor. Bu imgeler ve yazılar, yeni yetmelikten orta yaşa uzanan 30 yıllık bir ayrılık boyunca şehrin geçirmiş olduğu değişimleri anlamak için kişisel bir meydan okumayı temsil ediyor. Aynı zamanda geçmişi anlama arzusunu, insan ruhuna hitap ettiği biçimiyle kentsel ve doğal mekânın bir tür arkeolojisini de.

Benim için İzmir'e bakmayı ilginç kılan şeyin kişisel bir temeli var. Fakat bu büyüklükte herhangi bir şehir, bugünün seyahat programlarında sıkça yer almasa ve dünyanın kültürel, endüstriyel ve finansal merkezlerine yakından bağlı olmasa da bir miktar ilgi çekici olmalıdır. Şehir dört milyona yakın nüfusuyla demografik olarak homojen göründügünnde dahi, sosyolojik olarak ilgi uyandıran küçük dünyalar barındırması umulur. Bir dizi yeni akademik çalışma bunu gösteriyor. Şehrin, 17. yüzyılın sonunda on bin sakiniyle bir taşra yerleşiminden, 19. yüzyılın sonunda en kozmopolit ve "Avrupalı" Osmanlı liman şehrine, nihayet çöküşüne ve 1922'den sonra yeni bir yüze kavuşmasına uzanan dramatik tarihi de birçok tarihçi için ilgi çekicidir. Smyrna, aynı zamanda, dünyanın her yerine yayılmış Smyrnalıların soyundan gelenlerce uzaktaki bir geçmişe yansıtılan, Ermeni, Yahudi, Levanten ve özellikle Rumların hüzün ve gurur karışımı duygular imgeleminde özel bir yere sahiptir. 


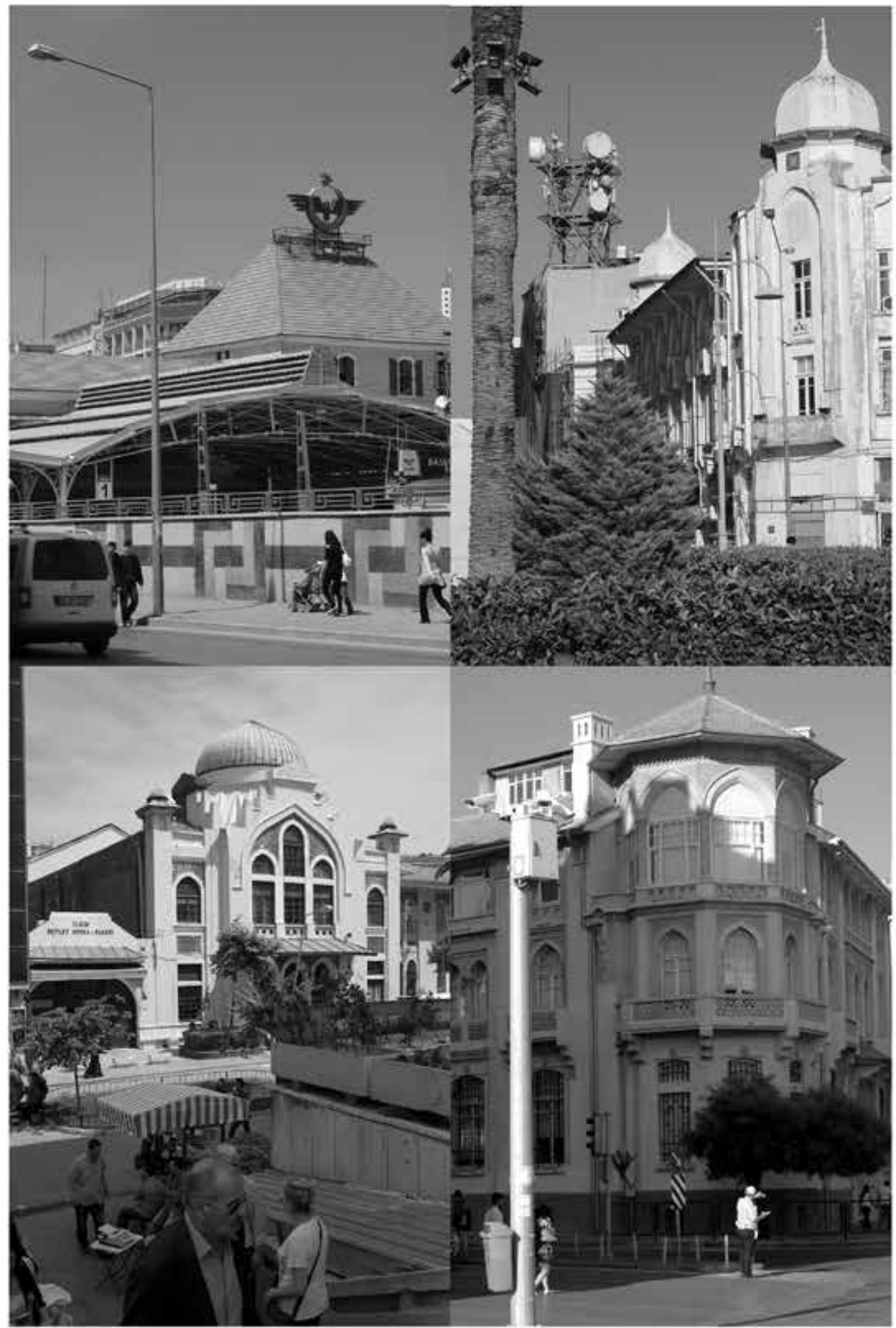


Meltem (December 2016)

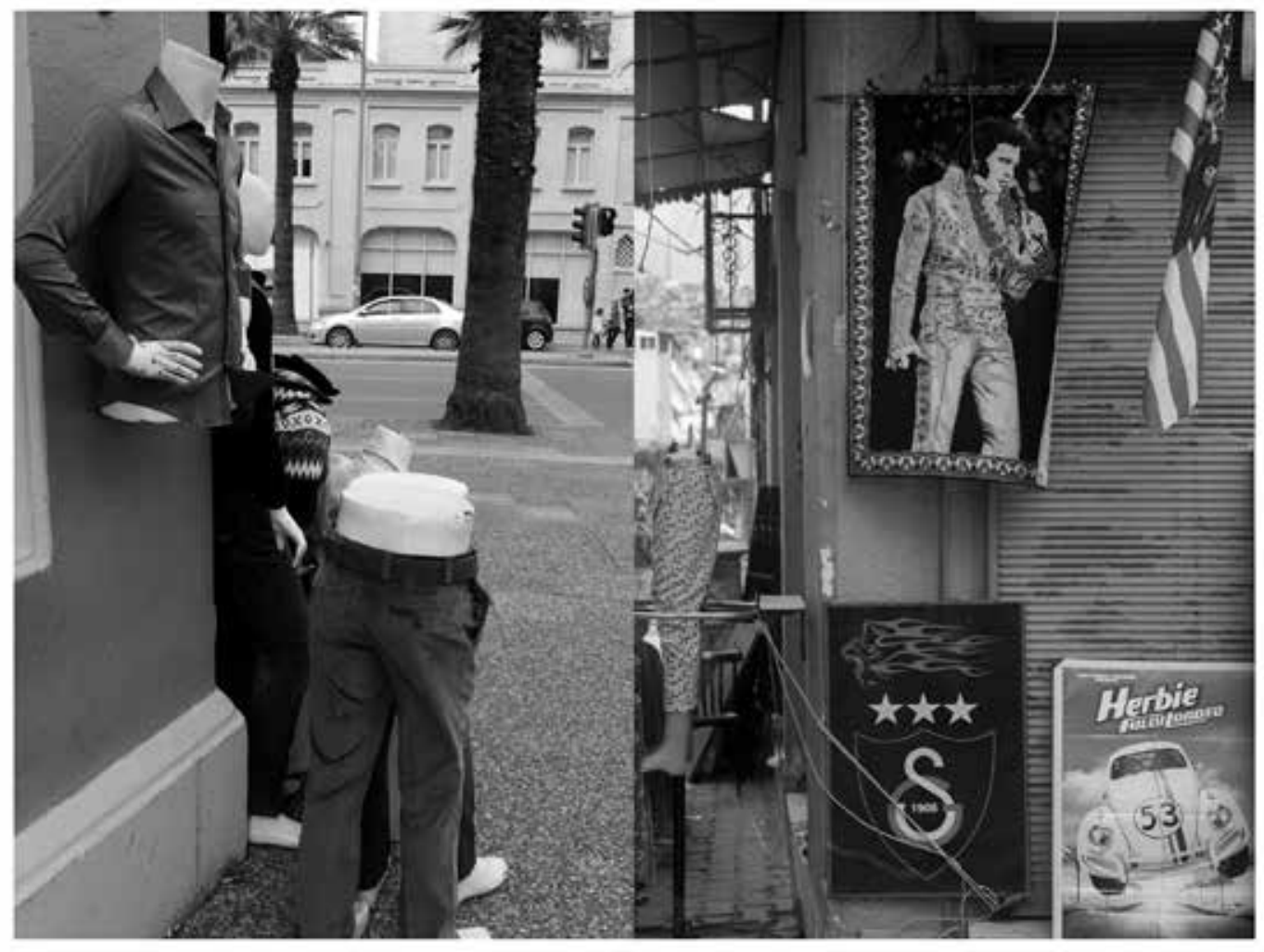


İncirlioğlu

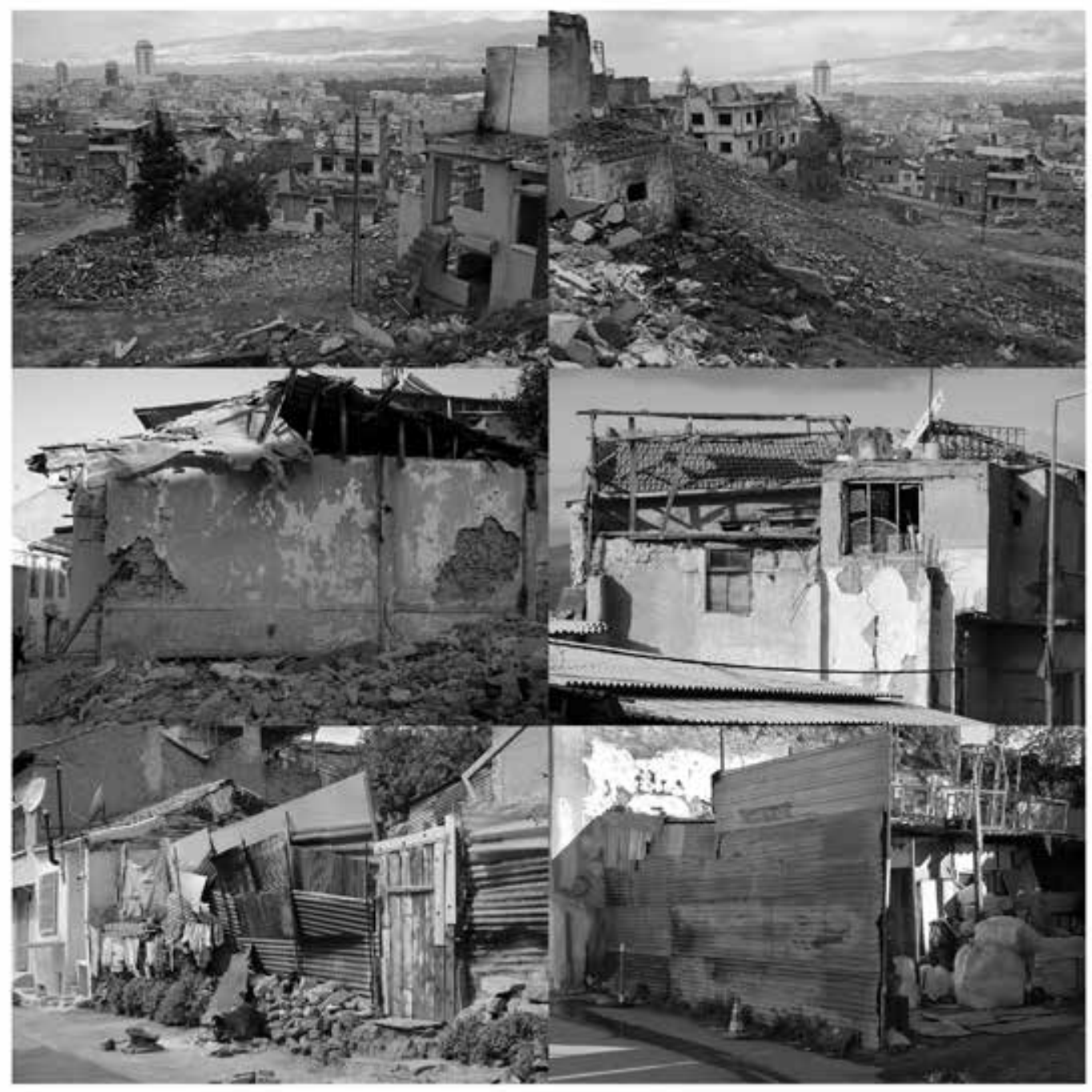




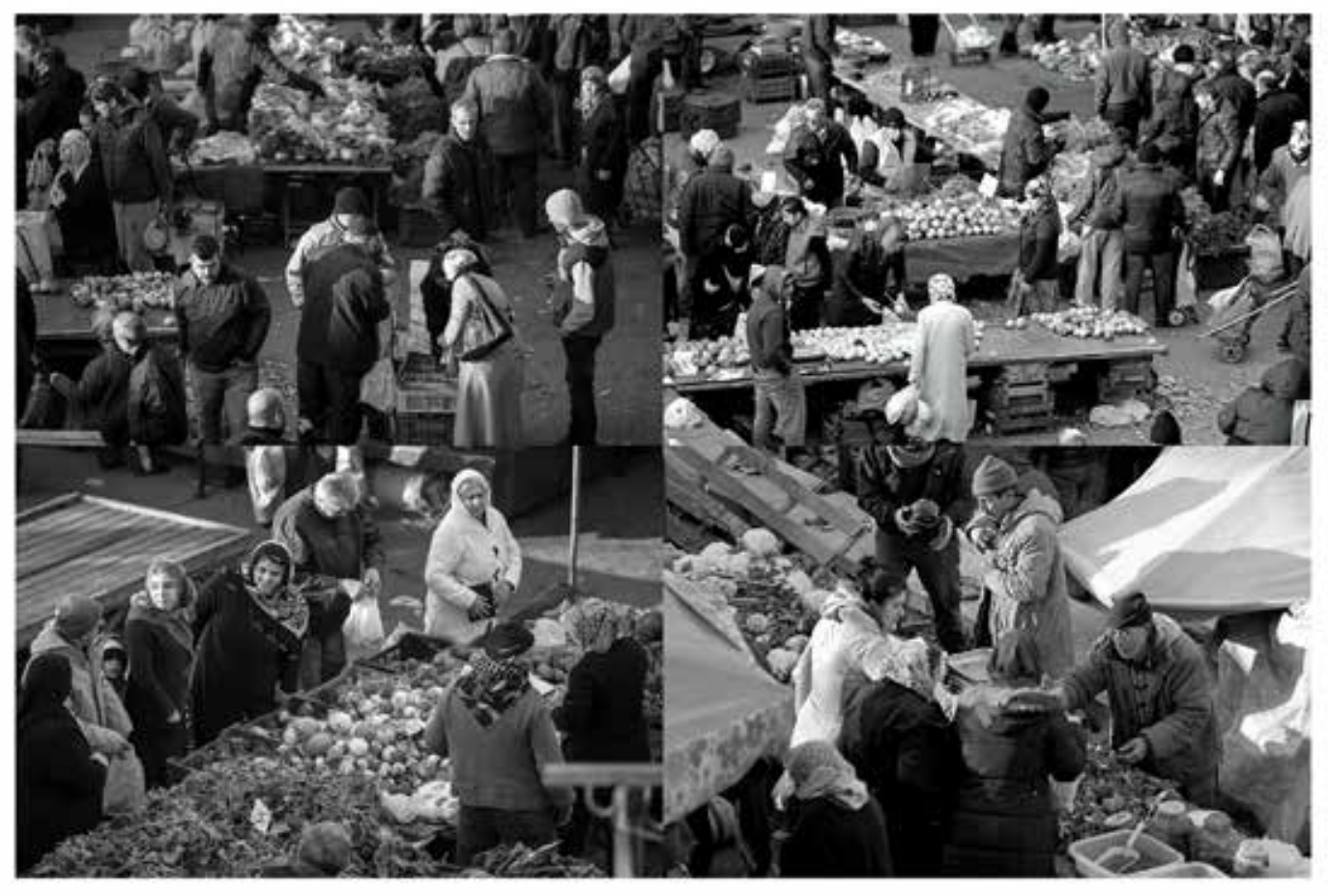


İncirlioğlu

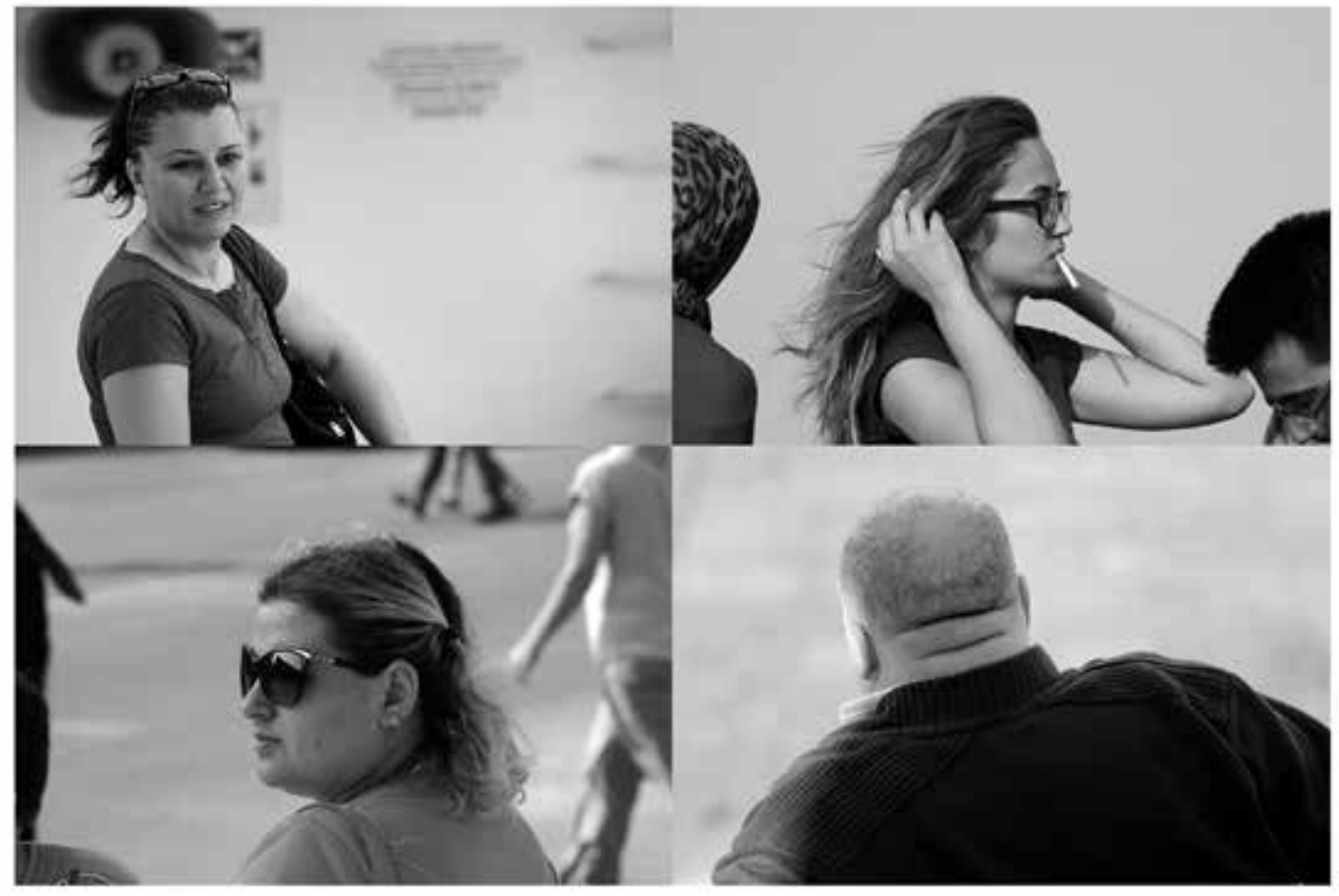

